\title{
Genetic monitoring of Eurasian beaver (Castor fiber) in Switzerland and implications for the management of the species
}

\author{
Silvan Minnig, Christof Angst \& Gwenaël Jacob
}

\begin{abstract}
Eurasian beaver (Castor fiber) has been reintroduced in Switzerland between 1956 and 1977. Individuals from the refugium population in France (C.f. galliae) were released in the Rhone catchment area and in tributaries of the Rhine catchment area in Western Switzerland. Individuals from the refugium populations from Norway (C.f. fiber) and Russia (C.f. orientoeuropaeus) were released in tributaries of the Rhine catchment in Eastern Switzerland. In the Rhine basin beavers of different origins came into contact. This study provides a first evaluation of the reintroduction program of beaver in Switzerland and gives implications for the post-release genetic management of the Swiss beaver population. We report on the genetic monitoring of the beaver population in Switzerland, based on the analysis of 251 dead found individuals collected from 1998 to 2014 and a combination of mitochondrial and nuclear genetic markers. We found no evidence of the presence of North American beaver (Castor canadensis) and we observed three mitochondrial DNA haplotypes, assigned to the refugium populations in France (C. $f$. galliae), Norway (C.f. fiber) and Germany (C.f. albicus). Based on the analysis of seven microsatellite loci, we inferred that the beaver population in Switzerland consists of two genetic clusters and we found evidence of a zone of secondary contact. We observed low levels of genetic diversity and we could show that individuals separated by distances up to $50 \mathrm{~km}$ were closely related.
\end{abstract}

KEY WORDS: Eurasian beaver, Castor fiber, reintroduction, microsatellites, population structure, inbreeding depression, relatedness.

Silvan Minnig [silvan.minnig@umweltbildner.ch]and Gwenaël Jacob, University of Fribourg, Department of Biology, Chemin du Musée 10, 1700 Fribourg, Switzerland; Christof Angst Biberfachstelle / Centre Suisse de Cartographie de la Faune (CSCF), Passage Maximilien de Meuron 6, CH-2000 Neuchâtel, Switzerland.

\section{Генетический мониторинг евразийского бобра (Castor fiber) и его практическое применение в управлении видом в Швейцарии}

\section{С. Миннинг, Х. Ангст, Г. Якоб}

РЕЗЮМЕ. Евразийский бобр (Castor fiber) был реинтродуцирован в Швейцарии в период с 1956 по 1977 г. Особи из автохтонной популяции C.f. galliae (Франция) были переселены в бассейн Роны, а также на притоки Рейна в западной части страны. Особи из норвежской $(C$. f. fiber) и воронежской (C. f. orientoeuropaeus) автохтонных популяций были выпущены на притоки Рейна в восточной Швейцарии. Таким образом, в бассейне Рейна обитают бобры разного происхождения. В нашем исследовании сделана первая оценка программы реинтродукции бобров в Швейцарии и даны практические рекомендации для последующего генетического менеджмента швейцарской популяции. Приведены материалы по мониторингу популяции бобров в Швейцарии на основе анализа 251 особи (звери найдены погибшими в период с 1998 по 2014 г.) и комбинации митохондриальных и ядерных генетических маркеров. Мы не нашли доказательств присутствия североамериканских бобров (Castor canadensis), но мы выделили три гаплотипа мтДНК, свойственных автохтонным бобрам Франции (C.f. galliae), Норвегии (C.f. fiber) и Германии (C.f. albicus). На основе анализа семи микросателлитных локусов было выявлено: а) существование на территории Швейцарии двух генетических кластеров бобровой популяции и б) свидетельство зоны вторичного контакта. Мы зарегистрировали низкий уровень генетического разнообразия и показали, что особи, разделенные дистанцией менее 50 км, являются близко родственными.

КЛЮЧЕВЫЕ СЛОВА: евразийский бобр, Castor fiber, реинтродукция, микросателлиты, структура популяции, инбредная депрессия, родственность. 


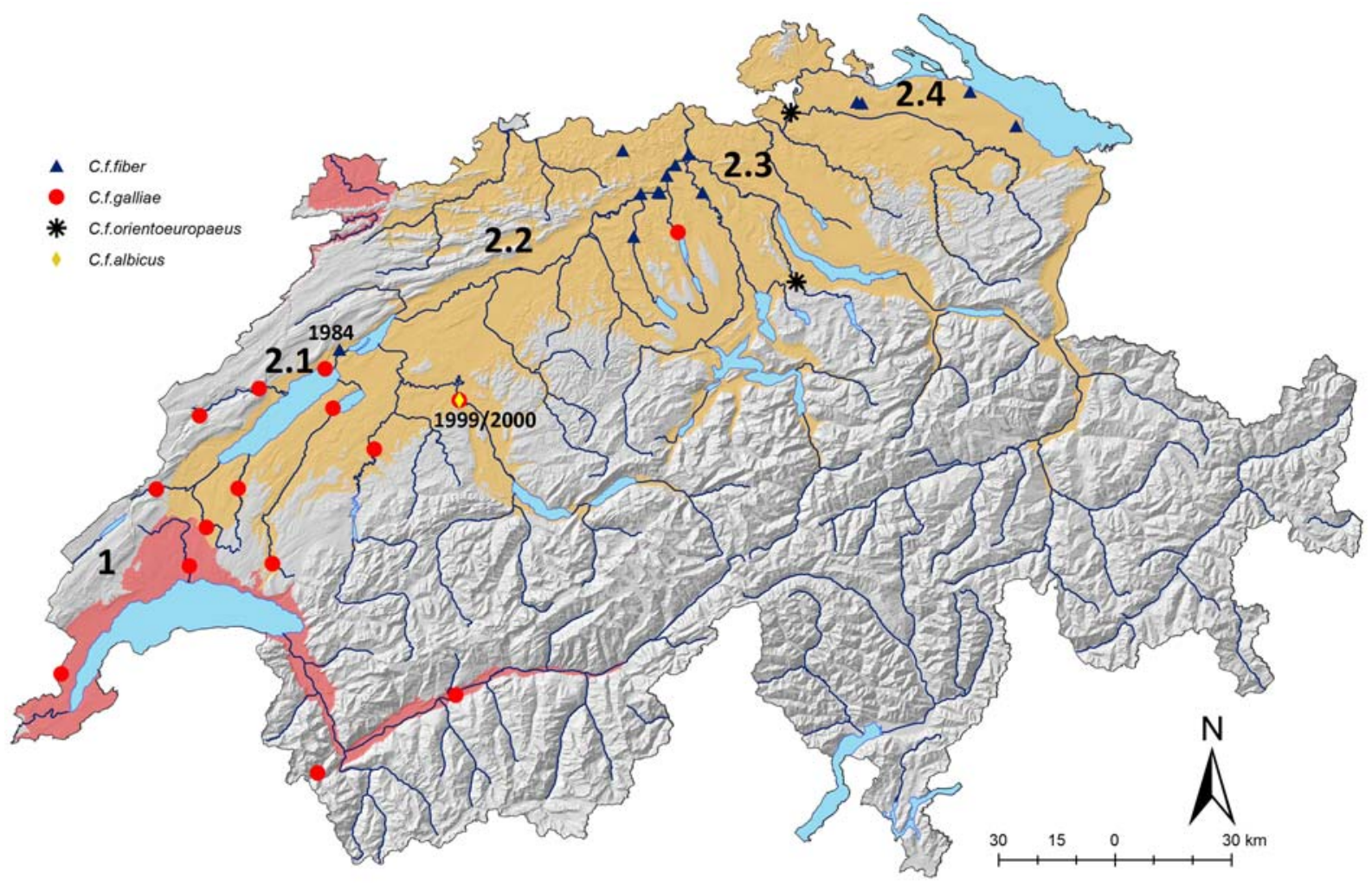

Fig. 1. Reintroduction of Castor fiber in Switzerland: from 1956-1977, 141 beavers have been released at 30 sites (44 events). Individuals from France (C.f. galliae, circles) were released in regions 1 and 2.1 and individuals from Norway (C. f. fiber, triangles) and Russia (C. f. orientoeuropaeus, asterisk) were released in region 2.3 and 2.4. Later, individuals of fiber origin were translocated from region 2.3 to region 2.1 in 1984 (1984). Two individuals from Bavaria (C. f. albicus, rhombus) and galliae origin escaped from captivity in 1999 and 2000 (1999/2000). Dark dyed area: Rhone catchment, light dyed area: Rhine catchment. Map: Biberfachstelle/CSCF, map-background: Swisstopo.

\section{Introduction}

To make a bridge between old and new classification of Eurasian beaver, we indicated the subspecies in brackets and called them refugium population. Individuals from three refugium populations in France (Castor fiber galliae), Norway (C. f. fiber) and Russia ( C. f. orientoeuropaeus; Ducroz et al., 2005; Durka et al., 2005; Senn et al., 2014) have been released in Switzerland. The refugium populations $C$. $f$. galliae and C. $f$. fiber belong to the Western Evolutionary Significant Unit (ESU, Moritz, 1994), C. f. orientoeuropaeus belongs to the Eastern ESU (Durka et al., 2005; Halley, 2011, but see also Frosch et al., 2014; Biedrzycka et al., 2014).

The last beaver population in Switzerland was extirpated at the beginning of the 19th century (Stocker, 1985) as a result of overhunting for fur, meat and castoreum (Dewas et al., 2012). Between 1956 and 1977, 141 individuals were imported from the Rhone valley (France), where the subspecies Castor fiber galliae was described, from the Telemark Region (Norway; C.f. fiber) and from Voronezh Province (Russia; C. $f$. orientoeuropaeus) and released into 30 sites (44 events) in Switzerland (Fig. 1). Twenty-one C.f. galli$a e$ individuals (hereafter galliae) were introduced in the Rhone catchment (Region 1 in Fig. 1), of which 14 survived (Stocker, 1985; Angst, 2010). Thirty-seven galliae individuals were released in the Three Lake region (Region 2.1 in Fig. 1) and four individuals were released in the surroundings of the city of Aarau (Region 2.3 in Fig. 1), of which in total 23 beavers survived. Seventy $C$. $f$. fiber individuals (hereafter fiber) and nine $C$. $f$. orientoeuropaeus individuals (hereafter orientoeur) were released in the region of Aarau (Region 2.3 in Fig. 1) and the region of Thurgau (Region 2.4 in Fig. 1), of which 29 and five survived, respectively. Nothing is known about the sex ratio of the reintroduced beavers. At least at one cite two males were unintentially reintroduced together (Stocker, 1985). Two individuals were translocated from Region 2.4 into Region 2.1 in 1984. Five individuals escaped from a zoological garden in the Region 2.1 in 1999 and 2000 respectively (Grossenbacher, 2005). Since 1993, the species has increased both in distribution range and numbers to reach 1600 individuals at the last census (Angst, 2010; Dewas et al., 2012) and 2800 individuals in 2015 (BAFU, 2016). Following this population expansion, experts recommend to downgrade the status of the beaver in Switzer- 
land from today still "critically endangered" (CR, Duelli, 1994). The red list of mammals is currently in revision.

In the present study, we used molecular techniques to monitor the Swiss beaver population and to address three main questions relevant for the conservation and management of the species:

1. We used mitochondrial DNA analysis to assign individuals to a species and determine if the North American beaver (Castor canadensis) was present in Switzerland.

2. We also assessed the level of genetic diversity of the beaver population in Switzerland and within refugium populations.

3. Finally we assessed the level of genetic structure of the beaver population in Switzerland to detect admixture zones between two regions in Switzerland.

\section{Material and methods}

Samples. We analysed 251 specimens found dead in Switzerland (241 with known location and ten without), of which 191 tissue samples (milt, liver and muscle) were collected by the Zentrum für Fisch- und Wildtiermedizin FIWI (University of Berne, Switzerland) between 1998 and 2014, and 43 hair samples and 17 tissue samples (tongue) were collected by cantonal authorities and game wardens between 2008 and 2013.

DNA Extraction. We extracted DNA from tissue samples using the Invisorb Spin Tissue Mini Kit (Stratec Molecular Company) following the manufacturer's recommendations. DNA from hair samples was extracted following standard Chelex extraction (Walsh et al., 1991; Goossens et al., 1998). The root of 15-50 hairs were cut, incubated for $5-6$ hours at $56^{\circ} \mathrm{C}$ in $400 \mu \mathrm{L}$ of a 5\% Chelex-100 solution (Bio-Rad) and for $8 \mathrm{~min}$ at $99^{\circ} \mathrm{C}$. After incubation, samples were centrifuged and the supernatant was transferred into a new tube for storage (Suenga \& Nakamura, 2005).

Analysis of the mitochondrial control region

DNA amplification. The hypervariable domain of the control-region of the mitochondrial DNA (mtDNACR) was amplified using the universal primers Thr-L 15926 and DL-H 16340 (Vila et al., 1999). Polymerase chain reactions (PCR) were set in $25 \mu \mathrm{L}$ volume, containing $12.5 \mu \mathrm{L}$ of Type-it Master Mix (Qiagen) and 0.3 $\mu \mathrm{M}$ of each primer. PCR conditions were as follows: an initial denaturation step at $94^{\circ} \mathrm{C}$ for $5 \mathrm{~min}$, followed by 35 cycles $\left(94^{\circ} \mathrm{C}\right.$ for $45 \mathrm{sec}, 50^{\circ} \mathrm{C}$ for $120 \mathrm{sec}$ and $72^{\circ} \mathrm{C}$ for $60 \mathrm{sec}$ ) and a final elongation step at $60^{\circ} \mathrm{C}$ for 15 min. PCR products were purified and sequenced (Sanger reaction).

Sequence analysis. Sequences were edited and aligned with SEQUENCHER (Gene Codes), BIOEDIT (Hall, 1999) and CLUSTAW (Thompson et al., 1994) for all 251 specimens. Phylogenetic relationship among haplotypes was assessed using Neighbor Joining (NJ) method in MEGA (Tamura et al., 2011). A NJ tree was constructed from the matrix of pairwise genetic dis- tances. Because of low variability in all sequences this simple distance method was used (Nei \& Kumar, 2000). We also included twelve $C$. fiber haplotypes (GenBank accession numbers AY623632-43) published in Ducroz et al. (2005), four $C$. fiber haplotypes (GenBank accession numbers DQ088700-03) published in Durka et al. (2005) and ten C. fiber haplotypes (GenBank accession numbers KC693753-62) published in Biedrzycka et al. (2014) in the NJ-tree. The tree was rooted with $C$. $c a$ nadensis haplotypes (ca1-ca3; GenBank accession numbers AY623644-AY623646) and the robustness of the NJ tree was tested with 1000 bootstrap replicates.

\section{Microsatellite analysis}

DNA amplification. All 251 individuals were genotyped at 11 microsatellites developed for American beaver (Crawford et al., 2008; Pelz-Serrano et al., 2009), of which six (Cca19, Cca20, Cca56, Cca62, Cca76 and Cca92) were modified and adapted for $C$. fiber by the group of P. Munclinger (unpublished data, personal communication). Two markers, Cca4 and Cca8 were excluded from further analyses due to suboptimal amplification. The remaining nine markers were labelled with fluorescent dyes as follows: Cca5, Cca13 and Cca62 (VIC), Cca18, Cca20 and Cca76 (PET), Cca19 (FAM), Cca56 and Cca92 (NED), and amplified in a single reaction (multiplex). PCR was performed using Qiagen master mix in $10 \mu 1$ reactions including 5 $\mu 1$ Type-it Master Mix (Qiagen), $3 \mu$ DNA, $2 \mu$ l primer mix with $0.2 \mathrm{mM}$ each $\mathrm{dNTP}$ and $0.3 \mu \mathrm{M}$ each primer. The following thermal cycling parameters were used: 15 min at $95^{\circ} \mathrm{C}, 29$ cycles of $30 \mathrm{~s}$ at $95^{\circ} \mathrm{C}, 90 \mathrm{~s}$ annealing at $56^{\circ} \mathrm{C}, 30 \mathrm{~s}$ at $72^{\circ} \mathrm{C}$, and final elongation of $30 \mathrm{~min}$ at $60^{\circ} \mathrm{C}$. For all PCR reactions positive and negative controls were included. DNA extracted from tissue samples was amplified in three replicates and DNA extracted from hair samples was amplified in four replicates. The fragment lengths were analysed on an ABI 3130 DNA Analyzer (Applied Biosystems), using Genescan LIZ500 (Applied Biosystems) as an internal size standard. Allele scoring was done with the software GENEMAPPER (Applied Biosystems).

Genotyping analysis. Out of 251 samples analysed, we selected 204 samples for which the sampling location was known and that were genotyped at a minimum of 5 microsatellites loci. We constructed a consensus genotype for each individual (based on 3-4 replicates, depending on the source of DNA) and we assigned individuals carrying gal mtDNA haplotype to $C$. $f$. galliae and those carrying fil mtDNA haplotype to $C$. $f$. fiber. We estimated the number of allele per locus, and the observed and expected heterozygosity at each locus and we tested for deviation from Hardy-Weinberg expectations (HWE) at each locus using the software GENALEX (Peakall \& Smouse, 2006).

Population genetic structure. We inferred the genetic structuring of the beaver population in Switzerland using STRUCTURE (Pritchard et al., 2000). We ran the admixture model with correlated allele frequencies to 


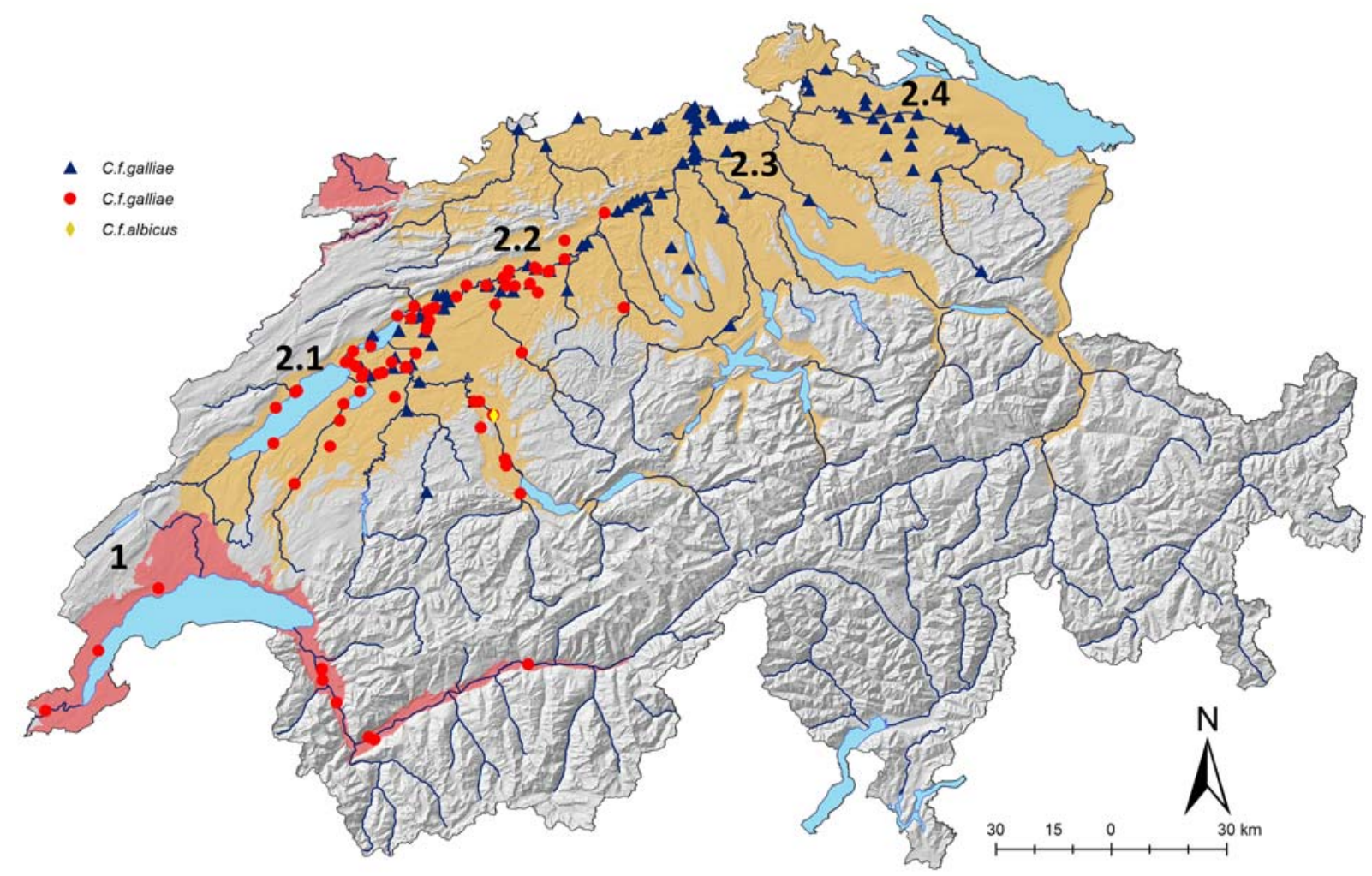

Fig. 2. Distribution of mitochondrial DNA haplotypes in Switzerland: fil (Castor fiber fiber, triangle), gal (C. f. galliae, circles) and $c f 5$ (C. f. albicus, rhombus). Dark dyed area: Rhone catchment, light dyed area: Rhine catchment. Map: Biberfachstelle/CSCF, map-background: Swisstopo.

test for the presence of $K=2-10$ genetic clusters. The most likely number of clusters was determined based on 5 iterations at each value of $K$ and following the recommendations of the user manual (Pritchard et al., 2000).

Spatial autocorrelation analysis. We used the spatial autocorrelation option in GENALEX (Peakall \& Smouse, 2006) to estimate the relationship between individual genotypes at seven microsatellite loci and the effective distance between individuals, following the assumptions that beavers only disperse along rivers and never cross land between river systems. Effective distance among individuals was calculated using ARCGIS (ESRI, 2011). The autocorrelation coefficient $r$ is a measure of the similarity between pairs of individuals whose locations falls within nine distances of 5-500 km. Random permutations of individuals among distance classes allowed us to draw the distribution of the autocorrelation coefficient under the null hypothesis of no spatial structure, which was used as a significance test.

\section{Results}

Mitochondrial amplification and mitochondrial haplotype analysis

We obtained a full sequence of the control region of the mitochondrial DNA (490 bp) from 251 individuals.
We found no evidence for the presence of North American beaver (C. canadensis) in Switzerland. We could identify three $C$. fiber haplotypes, which clustered (100 $\%$ similarity) with haplotypes from gal (C.f. galliae, Ducroz et al., 2005), fil (C. f. fiber, Ducroz et al., 2005) and cf5 (C.f. albicus, Biedrzycka et al., 2014). This latter haplotype was found in Region 2.1 and most likely correspond to individuals escaped from a zoological garden in 1999-2000. We did not find haplotypes assigned to C.f. orientoeuropaeus (Durka et al., 2005) although individuals from Voronezh (Russia) were released in Switzerland (Fig. 2).

Only haplotype gal was observed in Region 1, the three haplotypes were observed in Region 2.1, haplotypes gal and fil were observed in Region 2.3, and only haplotype $f i 1$ was observed in Region 2.4.

\section{Microsatellite analysis}

Genetic diversity and pairwise relatedness analysis

Mean number of alleles across loci ranged from 2.33 ( $g a l)$ to 2.67 ( $f i l$ ) and number of alleles per locus ranged from 1 to 6 (two loci, Cca5 and Cca72, were monomorphic). Significant overall deviation from Hardy-Weinberg equilibrium was detected in gal and fil individuals (Tab. 1). Four private alleles were found in fil individuals (loci Cca56 and Cca62). We found low 
Table 1. Diversity of the seven microsatellite loci used in the study. For each locus, we report the origin, galliae ( $g a)$ or $f i-$ ber $(f i)$, the sample size $(n)$, the observed numbers of alleles $(A o)$, the effective number of alleles $\left(A_{e}\right)$, observed heterozygosity $\left(H_{o}\right)$, expected heterozygosity $\left(H_{e}\right)$ and the outcome of test for deviation from Hardy-Weinberg expectations $(H W E$; ns, not significant; *, $p<0.05 ; * *, p<0.01 ; * * *, p<0.001)$.

\begin{tabular}{|c|c|c|c|c|c|c|c|}
\hline Locus & Origin & $\boldsymbol{n}$ & $\boldsymbol{A o}$ & $\boldsymbol{A}_{\boldsymbol{e}}$ & $\boldsymbol{H}_{\boldsymbol{o}}$ & $\boldsymbol{H}_{\boldsymbol{e}}$ & $\boldsymbol{H W \boldsymbol { E }}$ \\
\hline Cca13 & $f i$ & 127 & 3 & 1.61 & 0.370 & 0.379 & $* * *$ \\
\hline Cca13 & $g a$ & 76 & 3 & 1.67 & 0.289 & 0.399 & $* * *$ \\
\hline Cca18 & $f i$ & 127 & 2 & 1.77 & 0.417 & 0.434 & $\mathrm{~ns}$ \\
\hline Cca18 & $g a$ & 76 & 2 & 1.31 & 0.197 & 0.238 & $\mathrm{~ns}$ \\
\hline Cca19 & $f i$ & 125 & 3 & 1.97 & 0.408 & 0.491 & $* * *$ \\
\hline Cca19 & $g a$ & 73 & 3 & 1.63 & 0.329 & 0.385 & $* * *$ \\
\hline Cca20 & $f i$ & 127 & 2 & 1.67 & 0.189 & 0.399 & $* * *$ \\
\hline Cca20 & $g a$ & 76 & 2 & 1.41 & 0.276 & 0.292 & $\mathrm{~ns}$ \\
\hline Cca5 & $f i$ & 126 & 1 & NA & NA & NA & \\
\hline Cca5 & $g a$ & 76 & 1 & NA & NA & NA & \\
\hline Cca56 & $f i$ & 125 & 6 & 2.70 & 0.384 & 0.629 & $* * *$ \\
\hline Cca56 & $g a$ & 75 & 4 & 1.81 & 0.373 & 0.447 & ns \\
\hline Cca62 & $f i$ & 111 & 3 & 1.63 & 0.369 & 0.386 & $* * *$ \\
\hline Cca62 & $g a$ & 70 & 3 & 1.08 & 0.071 & 0.069 & $\mathrm{~ns}$ \\
\hline Cca72 & $f i$ & 127 & 1 & NA & NA & NA & \\
\hline Cca72 & $g a$ & 76 & 1 & NA & NA & NA & \\
\hline Cca92 & $f i$ & 127 & 3 & 1.10 & 0.079 & 0.090 & ns \\
\hline Cca92 & $g a$ & 76 & 2 & 1.55 & 0.276 & 0.354 & ns \\
\hline
\end{tabular}

levels of genetic differentiation between gal and fil individuals. $\left(F_{\mathrm{ST}}=0.01\right)$.

We inferred the presence of $K=5$ genetic clusters, however, the genetic distance among clusters (Fig. 3) suggests the presence of two groups of individuals assigned to C.f. galliae (hereafter galliae, clusters $2+$ $4+5$, probability of assignment $=0.9$ ) and to $C$. f. fiber (hereafter fiber, clusters $1+3$, probability of assignment $>0.9$ ).

We observed 67 individuals with haplotype gal and assigned to galliae in Regions 1 and 2.1, 100 individuals with haplotype $f i l$ and assigned to fiber in Regions 2.3 and 2.4, and a zone of admixture between galliae and fiber in Region 2.2 (most individuals with mixed ancestry). We also found evidence of nuclear genome replacement, as indicated by the occurrence of 34 individuals with haplotype $f i l$ and assigned to galliae and one individual with haplotype gal and assigned to fiber.

Spatial autocorrelation was positive and significant along the first four distance classes and suggests that individuals separated by distances up to $50 \mathrm{~km}$ are related to each other as first cousins ( $r=0.25$, Fig. 4).

\section{Discussion}

In the present study, we report on the genetic monitoring of the Swiss beaver population.
We found no evidence for the presence of North American beaver (C. canadensis) despite the intensive survey of the extent distribution range of the species. Nonetheless, regular surveys of the Swiss population and a close collaboration with neighbouring countries are required to monitor the expansion of North American beaver and its possible colonization of Switzerland (Dewas et al., 2012).

The 251 beavers analysed were assigned to Eurasian beaver and to three subspecies C. f. fiber, C. f. galliae and C. f. albicus, which Durka et al. (2005) grouped into a western phylogroup or Evolutionary Significant Unit. Assignment of individuals using both mitochondrial DNA (mtDNA) haplotypes and nuclear microsatellites loci mirrored the origin of the founder individuals. Indeed, individuals carrying haplotype ga 1 and assigned to galliae occurred predominantly in Western Switzerland, whereas those carrying haplotype fil and assigned to fiber occurred predominantly in Eastern Switzerland.

The observed admixture zone in Region 2.1 resulted primarily from the translocation in 1984 of at least one female fiber into an area dominated by galliae individuals, which led to the spread of the fil mtDNA haplotype. Hybridisation and several generations of backcrossing with galliae individuals led to the replacement of the fiber nuclear genome. This process 


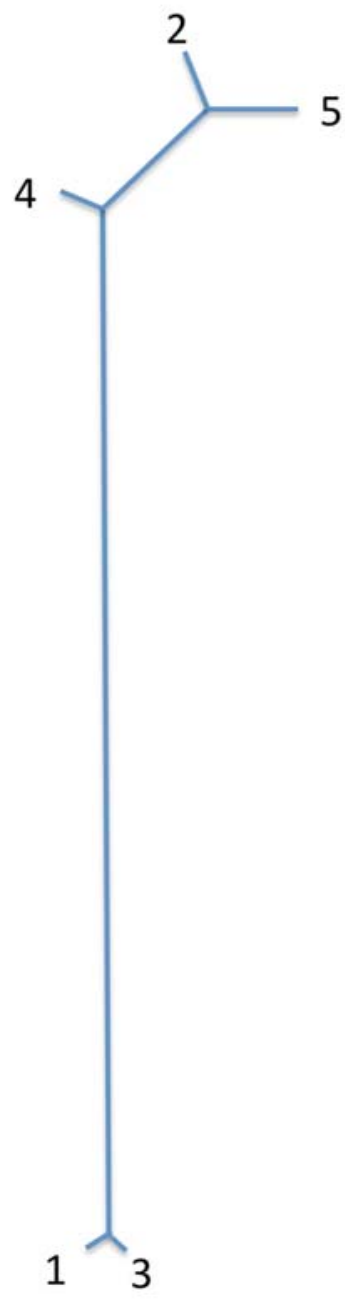

Fig. 3. Neighbour-Joining tree among the 5 genetic clusters. Individuals assigned to clusters 1 and 3 (bottom) were of fiber origin, individuals assigned to clusters 2,4 and 5 were of galliae origin.

resulted in individuals carrying fil haplotype (maternally inherited) and assigned to galliae based on the information of nuclear (bi-parentally inherited) microsatellite loci. Increase in range (from East to West and reverse; 2.3 and 2.4 to 2.1 ) and numbers of the beaver population reinforced the introgression between galliae and fiber genomes, and resulted in a large admixture zone in Region 2.2, where most individuals showed a mixed ancestry. Connection to the beaver population from Eastern Switzerland (Regions 2.3 and 2.4) via the River Aare favoured the spread of haplotype fil.

Two galliae individuals were released in Region 2.3, where only fiber individuals were present (Fig. 2). We did not detect haplotype gal in Region 2.3, despite of the large number of samples analysed, which suggests that this introduction attempt failed already in an early stage, or that only male individuals were released.

In Region 2.1 (especially in the southern part of this region near the city of Bern), we detected galliae and

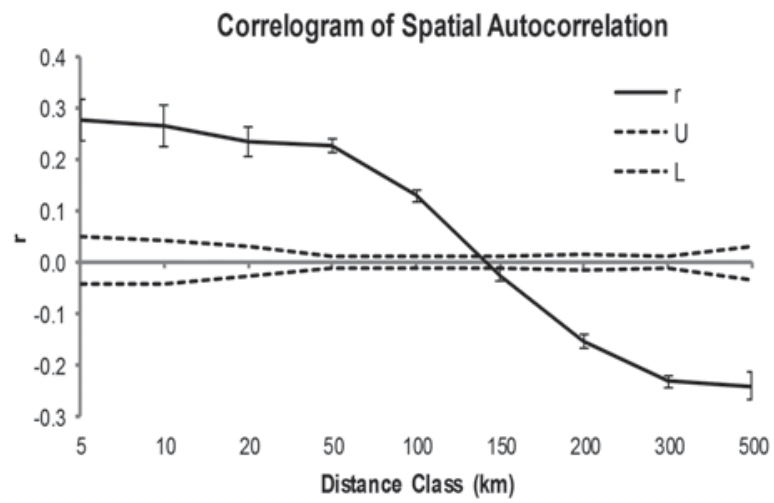

Fig. 4. Correlogram of pairwise genetic relatedness for nine distance classes ranging from 5 to $500 \mathrm{~km}$. $r$ is the coefficient of similarity between individual genotypes within distance class (solid line). Bootstrap error bars are also shown at each distance class. Dotted lines (U and L) are upper and lower confidence interval around the null hypothesis of no autocorrelation among genotypes within distance classes $(r=0)$.

fiber individuals, as well as an individual carrying a $C$. f. albicus haplotype. The River Aare upstream of the city of Bern was probably colonised originally by three galliae and albicus individuals that escaped in 1999 and 2000 from a zoological garden in the city of Bern. These two events explain the presence of the haplotypes gal and Cf5 along the River Aare. All the individuals analysed showed evidence of introgression, which suggests that there are no reproductive barriers among descendants from the three refugium populations.

Beavers from Voronezh, Russia, were introduced at two occasions in Regions 2.3 and 2.4 (Fig. 1), with six individuals released between 1975 and 1977 (River Sihl) and three individuals in 1977 (River Rhine; Stocker, 1985). Only the River Sihl was still occupied 2008 (Angst, 2010), but no evidence for the species presence was found in 2015. We did not find any individuals carrying a Voronezh haplotype. This result would suggest that the local population established along the River Sihl went extinct and was never connected to beaver population located downstream. Senn et al. (2014) detected an "Eastern" signal in the region where individuals from Voronezh or Belarus were released, which suggests that some $C$.f. ssp males have successfully reproduced and dispersed to neighbouring populations, and that their progeny survived. The analysis of additional individuals originating from Region 2.3 and 2.4 may allow us to better understand the colonization history of beaver in this area.

We found only three mtDNA haplotypes, one for $C$. f. galliae, C. f. fiber and C.f. albicus, which all were already reported in the literature (Durka et al., 2005; Biedrzycka et al., 2014). The low level of haplotype diversity reflects the low genetic variability in the beaver populations used as sources for the re-introduction program since 1956. Halley et al. (2012) estimated the minimum population size at 30 individuals in the lower 
Rhone (France), and 60-120 individuals in Telemark (Norway). For the Elbe-region (Germany), the minimum population size was estimated at 200 individuals (Halley et al., 2012) and this relatively large number of individuals may explain the higher level of genetic variability observed in this refugium population (Durka et al., 2005; Biedrzycka et al., 2014).

Low genetic diversity also negatively impacted our estimation of the number of genetic clusters. Although STRUCTURE (Pritchard et al., 2000) seems very appealing to infer the genetic structure of populations, the biological interpretation of $K$ genetic clusters is not trivial. The Bayesian algorithm implemented in STRUCTURE is adequate for data sets with discrete populations and may perform poorly in the presence of isolation by distance or inbreeding (Pritchard et al., 2000). Therefore, it makes sense to stress on estimations of $K$ which include most of the structure in the genotypes and that seem biologically sensible (Pritchard et al., 2000). In our study, $K=5$ had the highest likelihood. Based on the analysis of the genetic distances among the five genetic clusters, we concluded at the occurrence of two groups of genetically differentiated individuals in the Rhine basin (Region 2.1 to 2.4).

From the STRUCTURE output, it seems possible to identify migrants (Bergl \& Vigilant, 2006). We identified several putative long-distance migrants, but, from what is known about beaver dispersal in Switzerland, it seems unlikely that individuals would move over 150 $\mathrm{km}$ from Region 2.1 into Region 2.4 (The reintroduced beavers in Switzerland moved between 4 and $50 \mathrm{~km}$ on average; Stocker, 1985). This observation may be an artefact resulting from the low genetic variability in the Swiss beaver population at the seven variable microsatellite markers used in the present study. To our knowledge, no simulation studies have investigated the performance of the STRUCTURE algorithm to infer the genetic structure of populations and identify migrants when genetic diversity is low.

As a next step, we will infer the genetic structure of the Swiss population with the program STRUCTURE (Pritchard et al., 2000) by using reference individuals from the four refugium populations (France, Germany, Norway and Russia) used to repopulate Switzerland. Reference samples of known origin will improve our ability to detect admixture and quantify the level of ancestry for individuals collected in Switzerland and to compare our results with previous analyses of the Swiss population by Frosch et al. (2014) and Senn et al. (2014).

The analysis of autocorrelation based on Ritland's pairwise relatedness (Ritland, 1996, 2005) indicates that all individuals separated by distance up to $50 \mathrm{~km}$ are genetically related as first cousins. Despite of very low level of genetic diversity the beaver population in Switzerland has rapidly expanded, which suggests that inbreeding depression is low. Ongoing admixture between galliae and fiber individuals is expected to increase genetic diversity and to decrease the level of genetic relatedness among individuals.
Our results suggest that extent management actions, which consists in the revitalization of river-beds, the protection of riparian forests and to diminish river barriers like hydroelectric power stations are sufficient to promote the spatial expansion of the species. However, additional information is required about the potential positive and negative effects of the admixture between the two subpopulations. The next step will be to study the causes of beaver mortality (focusing on potential diseases) and to link the parasitic load of individuals with their level of inbreeding. Evidence for inbreeding depression may stress management actions to increase genetic variability, for instance by translocations of individuals between different regions of Switzerland. However, we also need to make sure that the admixture will not propagate diseases that are currently confined to galliae or fiber individuals (IUCN/SSC, 2013). Indeed, individuals within the refugium populations in France and Norway may have adapted to local diseases and there is a risk that contact zones between galliae and fiber individuals may favour the spread of diseases into areas where individuals are not adapted.

To conclude, the Eurasian beaver population from Switzerland has rapidly expanded, which suggests that the species is now firmly established. Additional studies will be conducted to fill gaps of knowledge on the species biology.

ACKNOWLEDGEMENTS. This study was supported by the Federal Office for the Environment FOEN, Switzerland. With special thanks to Marie-Pierre Ryser of the Zentrum für Fisch- und Wildtiermedizin FIWI (University of Berne, Switzerland) and the cantonal authorities of Geneva, Vaud, Valais, Neuchâtel, Fribourg, Bern, Solothurn, Basel-Land, Aargau, Zurich, Thurgau, St. Gallen, Schaffhausen and Grisons for providing us with the samples used in this study.

\section{References}

Angst C. 2010. Mit dem Biber leben. Bestandeserhebung 2008. Perspektiven für den Umgang mit dem Biber in der Schweiz. Bundesamt für Umwelt, Bern, und Schweizer Zentrum für die Kartographie der Fauna, Neuenburg, Umwelt-Wissen, No.1008. $156 \mathrm{~S}$.

BAFU 2016. Konzept Biber Schweiz. Vollzugshilfe des BAFU zum Bibermanagement in der Schweiz. Federal Office for the Environment. $43 \mathrm{~S}$.

Bergl R.A. \& Vigilant L. 2006. Genetic analysis reveals population structure and recent migration within the highly fragmented range of the Cross River gorilla (Gorilla gorilla diehli) // Molecular Ecology. Vol.16. No.3. P.501516.

Biedrzycka A., Konior B., Babik W., Swislocka M. \& Ratkiewicz M. 2014. Admixture of two phylogeographic lineages of the Eurasian beaver in Poland // Mammalian Biology. Vol.79. P.287-296.

Crawford J., Liu Z., Nelson T., Nielsen C. \& Bloomquist C. 2008. Isolation and characterization of microsatellite loci 
in the beaver Castor canadensis // Molecular Ecology Resources. Vol.8. P.616-618.

Dewas M., Herr J., Schley L., Angst C., Manet B., Landry P. \& Catusse M. 2012. Recovery and status of native and introduced beavers Castor fiber and Castor canadensis in France and neighboring countries // Mammal Review. Vol.42. P.144-165.

Ducroz J.F., Stubbe M., Saveljev A.P., Heidecke D., Samjaa R., Ulevièius A., Stubbe A. \& Durka W. 2005. Genetic variation and population structure of the Eurasian beaver Castor fiber in Eastern Europe and Asia // Journal of Mammalogy. Vol.86. No.6. P.1059-1067.

Duelli P. 1994. Rote Listen der gefährdeten Tierarten der Schweiz. Bern: Bundesamt für Umwelt, Wald und Landschaft. $93 \mathrm{~S}$.

Durka W., Babik W., Ducroz J.F., Hiedecke D., Rosell F., Samjaa R., Saveljev A.P., Stubbe A., Ulevièius A. \& Stubbe M. 2005. Mitochondrial phylogeography of the Eurasian beaver Castor fiber L. // Molecular Ecology. Vol.14. No.12. P.3843-3856.

ESRI 2011. ArcGIS Desktop: Release 10. Redlands, CA: Environmental Systems Research Institute.

Frosch C., Kraus R.H.S., Angst C., Allgöwer R., Michaux J., Teubner J. \& Nowak C. 2014. The genetic legacy of multiple beaver reintroductions in Central Europe // PLoS ONE. No.9(5): e97619.

Goossens B., Waits L.P. \& Taberlet P. 1998. Plucked hair samples as a source of DNA: reliability of dinucleotide microsatellite genotyping // Molecular Ecology. Vol.7. P.1237-1241.

Grossenbacher K. 2005. 40 Jahre Biber Castor fiber im Kanton Bern und angrenzenden Gebieten Beobachtungen 1996-2005 // Mitteilungen der Naturforschenden Gesellschaft. Bd.62. S.54-106.

Hall T.A. 1999. BioEdit: a user-friendly biological sequence alignment editor and analysis program for Windows // Nucleic Acids Symposium Series. No.41. P.95-98.

Halley D.J. 2011. Sourcing Eurasian beaver Castor fiber stock for reintroductions in Great Britain and Western Europe // Mammal Review. Vol.41. P.40-53.

Halley D., Rosell F. \& Saveljev A. 2012. Population and distribution of Eurasian beaver Castor fiber // Baltic Forestry. Vol.18. No.1. P.168-175.

IUCN/SSC. 2013. Guidelines for Reintroductions and Other Conservation Translocations. Version 1.0. Gland, Switzerland: IUCN Species Survival Commission. 57 p.

Moritz C. 1994. Applications of mitochondrial DNA analysis in conservation - a critical review // Molecular Ecology. Vol.3. P.401-411.

Nei M. \& Kumar S. 2000. Molecular Evolution and Phylogenetics. Oxford: Oxford University Press. 352 p.

Peakall R. \& Smouse P.E. 2006. GENALEX 6: genetic analysis in Excel. Population genetic software for teach- ing and research // Molecular Ecology Notes. Vol.6. P.288-295.

Pelz-Serrano K., Munguia-Vega A., Piaggio A.J., Neubaum M., Munclinger P., Partl A., Van Piper C. \& Culver M. 2009. Development of nine new microsatellite loci for the American beaver, Castor canadensis (Rodentia: Castoridae) and cross-species amplification in the European beaver, Castor fiber // Molecular Ecology Resources. Vol.9. P.551-554.

Pritchard J.K., Stephens M. \& Donnelly P. 2000. Inference of population structure using multilocus genotype data // Genetics. Vol.155. P.945-959.

Ritland K. 1996. Estimators for pairwise relatedness and individuals inbreeding coefficient // Genetic Research. Vol.67. P.175-185.

Ritland K. 2005. Multilocus estimation of pairwise relatedness with dominant markers // Molecular Ecology. Vol.14. P.3157-3165.

Senn H., Ogden R., Frosch Ch., Syruckova A., CampbellPalmer R., Munclinger P., Durka W., Kraus R.H.S., Saveljev A.P., Nowak C., Stubbe A., Stubbe M., Michaux J., Lavrov V., Samiya R., Ulevièius A. \& Rosell F. 2014. Nuclear and mitochondrial genetic structure in the Eurasian beaver Castor fiber - implications for future reintroductions // Evolutionary Applications. Vol.7. No.6. P.645-662.

Stocker G. 1985. Biber Castor fiber L. in der Schweiz. Probleme der Wiedereinbürgerung aus biologischer und ökologischer Sicht. Birmensdorf: Swiss Federal Institute of Forestry Research. Bericht No.274. 149 S.

Suenga E. \& Hakamura H. 2005. Evaluation of three methods for effective extraction of DNA from human hair // Journal of Chromatography. No.820. P.137-141.

Tamura K., Peterson D., Peterson N., Stecher G., Nei M. \& Kumar S. 2011. MEGA5: Molecular evolutionary genetics analysis using maximum likelihood, evolutionary distance, and maximum parsimony methods // Molecular Biology and Evolution. Vol.28. P.2731-2739.

Thompson J.D., Higgins D. \& Gibson T. 1994. CLUSTAL W: improving the sensitivity of progressive multiple sequence alignment through sequence weighting, position-specific gap penalties and weight matrix choice // Nucleic Acids Research. Vol.22. P.4673-4680.

Vila C., Amorim I.R., Leonard J.A., Posada D., Castroviejo J, Petrucci-Fonseca F., Crandall K.A., Ellegren H. \& Wayne K. 1999. Mitochondrial DNA phylogeography and population history of the grey wolf Canis lupus // Molecular Ecology. Vol.8. P.2089-2103.

Walsh P., Metzger A.D. \& Higuchiet R. 1991. Chelex 100 as a medium for simple extraction of DNA for PCR-based typing from forensic material // BioTechniques. Vol.10. No.4. P.506-513. 